\title{
Kan du nå saltet?
}

\author{
Kierkegaard i dialog med høflighedsforskningen \\ i moderne sociolingvistik
}

\author{
Sogneprast, ph.d. \\ Dorothea Glöckner
}

\begin{abstract}
This article brings into dialogue Kierkegaard and modern sociolinguistics. A common starting point is provided by focussing on indirect communication. For what occurs between meaning and saying? And to what extent can social relations be influenced by indirect communication? Included is the survey by P. Brown and S.C. Levinson, Politeness. Some universals in language usage (1987) as well as latest studies on impoliteness that consider strategies of conflict avoiding communication. Kierkegaard also shows that human communication has to include the receiver. Nevertheless, his thoughts on communication are at the same time fundamentally embedded in analyses of human selfconception. Reflections upon these thoughts are then addressed using Kierkegaard's work, The Sickness Unto Death. In these selected encounters between Kierkegaard and sociolinguistics, ethical challenges of speech acts are approached as topic of a potential dialogue.
\end{abstract}

Key words: Kierkegaard - sociolinguistics - situation - face - facethreatening acts - conflictavoiding speech - between meaning and saying - ethic of communication

"Kan du nå saltet?" Dette spørgsmål er et klassisk eksempel på en sætning med en underforstået betydning. Den der siger det interesserer sig jo næppe for, hvorvidt modtageren er i stand til at nå saltet eller ej. Han beder om en håndsrækning. Men selvom opfordringen gemmer sig under de udtalte ord, er det dog konventionelt umuligt at misforstå, hvad der er meningen med det, der bliver sagt.'

Her er der fremført en kommunikativ strategi, der bærer præg af indirekthed. Og analyser af denne og tilsvarende strategier fremstår centralt indenfor høllighedsforskningen, der her skal introduceres som en gren af den moderne sociolingvistik. Hensigten er, at påpege

1. Jf. Penelope Brown \& Stephen C. Levinson, Politeness. Some universals in language usage (Cambridge: Cambridge University Press 1987), 70. 
denne videnskabsgren som en oplagt partner for en dialog med Kierkegaards kommunikations- og meddelelsesteoretiske tænkning. Dermed vil jeg argumentere for, at Kierkegaard og den sociolingvistiske høflighedsforskning på trods af deres forskellige forudsætninger gensidig kan åbne perspektiver i hinandens analyser.

Jeg begynder med en overordnet præsentation af høflighedsforskningen og introducerer Kierkegaard som partner i en potentiel dialog (afsnit 1). Dernæst introducerer jeg enkelte sociolingvistiske problemstillinger, der synes relevante i forhold til Kierkegaard. Her præsenterer jeg især den vejvisende analyse af Penelope Brown og Stephen C. Levinson angående sproglige høflighedsstrategier, der fremføres som måder at forholde sig til den andens krav på anerkendelse på. ${ }^{2}$ Desuden strejfer jeg kort Browns og Levinsons reception i den nyere Impolitenessforskning, ${ }^{3}$ for derved at fremdrage konfliktundgående talestrategier, der modificeret også kan spores hos Kierkegaard (afsnit 2).

For at påpege grundlæggende hermeneutiske forudsætninger i den potentielle tværfaglige dialog, tematiserer jeg - meget overordnet - Kierkegaards sammenknytning af menneskets selvforståelse og sprogbrug (afsnit 3). Endelig inddrager jeg, med udgangspunkt i to af Kierkegaards taler fra hhv. 1844 og 1845, et konkret tilløb til selve dialogen. Dette tilløb består i reflektioner over, hvordan en menneskelig samtale kan begyndes hhv. afsluttes. Analysen relaterer sig til de samtalefaser, der i afsnit 2 blev nævnt i forbindelse med konfliktundgående strategier. Dermed forsøger jeg ligeledes, at antyde et muligt anknytningspunkt mellem kierkegaardske og sociolingvistiske analyser (afsnit 4). Konkluderende fremhæver jeg enkelte perspektiver for den tværfaglige dialog. Her efterlyser jeg især et koncept for den varsomme tale, der forholder sig til menneskets begrænsede selvindsigt (afsnit 5).

\section{Høflighedsforskningen og Kierkegaard - oplagte partnere for en dialog?}

Den sociolingvistiske høllighedsforskning undersøger interkulturelle relationer ved at bruge "høfligheden" som et værktøj til at beskrive kvaliteten af sociale interaktioner. Langt mere end bare at fremstå

2. Penelope Brown and Stephen C. Levinson, Politeness. Some universals in language usage (Cambridge: Cambridge University Press 1987), første gang publiceret i: Questions and politeness. Strategies in social interactions, red. Esther N. Goody (Cambridge: Cambridge University Press 1978).

3. Jf. Derek Bousfield, Impoliteness in Interaction (Amsterdam/Philadelphia: John Benjamins Publishing Company 2008), 3f. 
som rådgivning for almindelig pli og opførsel analyserer denne videnskab sociale normer og deres betydning for kommunikationen. Blandt andet undersøges relationer mellem sprog, magt og vold og i denne sammenhæng også konfliktundgående strategier. ${ }^{4}$ Gennem de sidste tre årtier har "høflighed" dermed været et aktuelt og stærkt omdiskuteret emne indenfor sociolingvistikken. ${ }^{5}$

Den videnskabelige interesse retter sig ikke mindst på afstanden mellem det, der siges eksplicit og det sagtes implicitte mening. For differensen mellem ytring og intention medfører ikke kun potentielle misforståelser, den kan også give udtryk for en bevidst hensyntagen til modtageren. Når jeg fx undgår at sige hvad jeg mener, kan jeg derved prøve på, at oprette eller vedligeholde en relation til modtageren, der fremmer mine mål.

Denne almindelige indsigt undersøges samtidig i forhold til de sociale hierarkier og asymmetriske magtforhold, der giver anledning til brugen af tilsvarende strategier.

Forskningsmetoden er både teoretisk og pragmatisk. Den analyserer konkrete ytringer, samtaler og samtalesituationer, hvorved der skelnes mellem undersøgelser af første hhv. anden orden. I den første orden indgår analyser af sproglige normer, der foretages af de sociale aktører selv, mens den anden orden står for en teoretisk refleksion, der dog fortsat tager udgangspunkt i de medvirkendes selvforståelse. ${ }^{6}$

\section{Kierkegaard som mulig dialogpartner}

Et forsøg på, at påpege muligheden for en dialog mellem Kierkegaard og sociolingvistiske studier kræver en særlig redegørelse. Er der overhovedet nogle fælles emner?

Mit hovedargument i denne sammenhæng er, at der i begge teoretiske universer rettes en særlig opmærksomhed på indirekte kommunikationsformer. Især Kierkegaards indirekte meddelelsespraksis ${ }^{7}$

4. Jf. Steffen Kitty Herrmann \& Hannes Kuch, "Verletzende Worte. Eine Einleitung", Verletzende Worte. Die Grammatik sprachlicher Missachtung, red. Steffen K. Herrmann, Sybille Krämer \& Hannes Kuch (Bielefeld: transcript 2007), 17-22. 5. Jf. Liisa Vilkki, "Politeness, Face and Facework: Current Issues", A Man of Measure. In Honour of Fred Karlsson (2006), 322-332 (322).

6. Jf. Miriam A. Locher og Derek Bousfield "Introduction. Impoliteness and power in language", Impoliteness in Language. Studies on its Interplay with Power in Theory and Practice, red. Derek Bousfield og Miriam A. Locher (Berlin / New York: Mouton de Gruyter 2008), 5.

7. Ved at tale om „meddelelsespraksis“ tænkes her på Kierkegaards brug af den sokratiske majeutik, der står bag ved konstruktionen af hans polyphone pseudonyme univers, hvorved han vil tilskynde sin læser til at formulere sin egen stemme. Teoretiske refleksioner over denne meddelelsesform findes i et udkast under titlen "Den ethiske og den ethisk-religieuse Meddelelses Dialektik" fra 1847, Søren Kierkegaards Skrifter (København: Gad 2003), bd. 27, 389-434 (herefter citeret som SKS, efter- 
tilbyder sig med sin komplekse og meget varierede tilgang som en oplagt inspiration for tilsvarende sociolingvistiske undersøgelser. Dermed er dog ikke ment, at fx Kierkegaards brug af ironien eller hans pseudonyme forvirringer skulle udsættes for et høflighedstjek. Langt nærmere kan Kierkegaards hermeneutiske forudsætninger diskuteres som et korrektiv til sociolingvistikkens formålsrettede tolkning af talehandlinger. For hvad motiverer talens indirekthed? Og hvad er forholdet mellem de hensyn, den talende tager til sig selv, og de hensyn, der tages til modtageren?

Et første anknytningspunkt for en tværfaglig dialog består i, at sociolingvistikkens opmærksomhed på konkrete talesituationer tager udgangspunkt $\mathrm{i}$ et begrebsligt koncept, der er inspireret af Kierkegaard. Blandt andet tager Karl Jaspers eksistensfilosofiske analyser af menneskets "grundsituation" udgangspunkt i Kierkegaards opfattelse af "situationen", som en "baggrund af samtidigt tilstedeværende ydre momenter, som er bestemmende for, hvorledes et menneskes optræden (tale el. handlen) er at forstå".

Høflighedsforskningen argumenter dog vidtgående ud fra behovsteorier, mens Kierkegaard peger på menneskets indre situerethed som grundlæggende forudsætning for enhver samtalesituation. Netop disse præmisser er afgørende for, at kløften mellem ytring og intention tolkes forskelligt. Høflighedsforskningen analyserer det sagte i forhold til det ikke-sagte, mens Kierkegaard derudover også tematiserer ytringens u-udsigelige dimension.

På trods af disse forskellige forudsætninger synes det alligevel oplagt, at konfrontere begge tilgange med hinanden. Spørgsmålet om meningen af det udtalte ord får ganske vist hos Kierkegaard en dybere klangbund. Men udfordringen er, hvordan Kierkegaards analyser kan formidles i andre kontekster. Og her synes den sociolingvistiske høllighedsforskning at tilbyde en række anknytningspunker, som jeg nu vil prøve på, at udfolde nærmere.

fulgt af bind og sidetal). Ud over disse bevidst konstruerede indirekte meddelsesformer findes i Kierkegaards tekster desuden en "dybere dimension", der ligeledes transporterer indirekte meddelelser, som ofte modsiger eller ophæver det eksplicit sagte (jf. Hans Christian Wind, Religion og Kommunikation. Teologisk hermeneutik (Aarhus: Aarhus Universitetsforlag 1987), 63.

8. Gregor Malantschuk, Nøglebegreber i Søren Kierkegaards tønkning (København: Reitzel 1992), 149. 


\section{Høflighed som hensyn til den andens "ansigt"}

I dette afsnit fremlægges udvalgte sociolingvistiske analyser af strategier, der går ud på, at værne om hinandens selvrespekt. Dermed forbereder jeg en efterfølgende drøftelse af, hvilke hensyn der burde tages til modtageren i en kommunikativ situation.

Fremstillingen tager udgangspunkt i P. Brown og S.C. Levinsons værk Politeness. Some universals in language usage (Cambridge: 1987), som er et standardværk, der på trods af dets snart 30-årige receptionshistorie fortsat fremstår som en førende tilgang indenfor sociolingvistikken. Denne interkulturelle analyse undersøger strategiske sproglige hensyn, der tages i en samtale for at værne om hinandens "ansigt". Under "ansigt" (face) forstås modtagerens og afsenderens offentlige selvbillede, som forbindes med kravet om respekt.

\section{"Politeness" som basis for sociale relationer}

P. Brown og S.C. Levinson tager udgangspunkt i et enkelt spørgsmål. Hvordan afgør vi, hvad en anden mener med det, han siger? Beder han om noget, kritiserer eller klager han? De udtalte ord er i denne sammenhæng langt mindre afgørende end lingvistiske detaljer, som kombineres blandt andet med vores kropssprog. Ud fra denne iagttagelse undersøger Brown og Levinson på tværs af forskellige kulturer universale strategier for verbal interaktion (jf. Brown, Levinson 1987, 57).

Deres teoridannelse har to præmisser. Alle kompetente medlemmer af et samfund har 1) et offentligt selvbillede (face) og 2) rationelle evner, som muliggør en strategisk tilgang til de behov, der er knyttet til dette selvbillede, der defineres som sammensat af et negativt og et positivt "ansigt" ( face). Teorien er inspireret af Emile Durkheims bestemmelse af positive og negative riter og delvis formidlet gennem Erving Goffmanns "ansigts"-begreb (Brown 1987, 57 og 61). Det negative ansigt bestemmes som krav på handlingsfrihed og som krav på ikke at blive generet $\mathrm{i}$ ens foretagender. Det positive ansigt bestemmes derimod som krav på anerkendelse af de værdier og handlinger, som den enkelte selv vurderer som personlige styrker. Det er dog ingen selvfølge, at disse krav imødekommes (face respect), men de giver udtryk for et behov, som vi kan tilfredsstille, eller hvis opfyldelse vi kan nægte (Brown 1987, 62). På den anden side indebærer det forudsatte rationalitetsbegreb, at vi kan afveje forskellige midler til at opnå et tilstræbt mål, for derefter at vælge det middel, som opfylder dette mål med det bedst mulige resultat og de mindste omkostninger.

I denne sammenhæng bliver hølighedens strategier relevante. For hvis jeg vil realisere mine mål optimalt, må jeg tage hensyn til de krav, der er knyttet til den andens offentlige selvbillede. Samtidig 
repræsenterer mine mål oftest en trussel for den andens selvbillede (face threatening act, forkortet FTA).

Disse "ansigtstruende overgreb" $(F T A)$ inddeles i forhold til om det er den andens negative eller positive ansigt, der bliver truet. Således fremstår for eksempel befalinger, ønsker, forslag, gode råd, formaninger, trusler og advarsler på den ene side samt tilbud og løfter på den anden side som en indskrænkning af den andens selvbestemmelse og dermed som trussel overfor hans negative ansigt. Omvendt nægter for eksempel følgende talehandlinger at imødekomme den andens krav om anerkendelse af hans positive ansigt: verbaliseringer af stærke emotioner, at bringe emotionel ladede eller potentiel polariserende emner på tale, at bringe tabuiserede emner på tale eller en demonstrativ nægtelse af at vise opmærksomhed (jf. Brown 1987, 65ff).

Denne liste suppleres med en oversigt over yderligere talehandlinger, som truer ens eget "ansigt". Her nævnes for eksempel modtagelsen af undskyldninger, retfærdiggørelser og ufrivillige løfter som en krænkelse af ens personlige krav på selvbestemmelse og dermed som krænkelse af ens "negative ansigt", mens på den anden side undskyldninger, modtagelsen af komplimenter, tilståelser og emotionelle udbrud anføres som krænkelser af ens "positive ansigt" (Brown 1987, 67f).

Dette differentierede spektrum af ansigtstruende talehandlinger nødvendiggør dermed en balancering af de krav, der knyttes til både ens eget og modtagerens offentlige selvbillede. Og det er ud fra denne iagttagelse, at Brown og Levinson undersøger, hvorvidt denne balance kan opnås gennem sproglige høflighedsstrategier.

Også her differentieres der mellem to former. Den positive høflighed sigter mod at opfylde den andens behov for anerkendelse, mens den negative høflighed sigter mod at opfylde den andens basale krav for selvbestemmelse (Brown 1987, 70). På baggrund af de strategier, der anvendes i begge sammenhænge, er det Browns og Levinsons anliggende, at påvise forskydninger mellem ytring og mening, samt at diskutere intentionelle begrundelser for disse forskydninger.

\section{Kierkegaard og "Politeness"analyser?}

Ovenstående introduktion af Browns og Levinsons projekt har rettet særlig fokus på deres interesse for indirekte kommunikationsformer. Denne interesse viser sig især i analyser af den negative hølighed, der defineres som væsentlig konfliktundgående, samtidig med at den karakteriseres gennem formel korrekthed og selvbeherskelse. Yderligere indsættes der en konventionel indirekthed, for at opnå et kompromis mellem åbenlyse og mindre åbenlyse fremgangsmåder (Brown 1987, 70). 
Både Kierkegaard og Brown/Levinson undersøger dermed talestrategier med særlig henblik på, hvordan modtageren kan opnå en forståelse af afsenderens intentioner gennem det, der ikke bliver sagt. Ud fra denne målsætning sigter disse strategier hverken på at skabe misforståelser eller på at vildlede kommunikationen. I begge teoridannelser står der snarere et dobbelt sandhedskrav på spil. På den ene side vedrører dette krav sandfærdigheden i de mål, som den enkelte sætter sig for sin tale, på den anden side vedrører dette krav sandfærdigheden i de mellemmenneskelige relationer. Sandheden kan ikke siges i form af en ansigtstruende handling. For også måden at kommunikere på er afgørende for selve meddelelsens sandhedsværdi. Men hvordan skal det der er sandt - for mig - så siges?

Den sokratiske løsning er her, at den anden skal sættes i stand til at sige sig selv, hvad jeg har at sige til ham. Overordnet synes det at være det samme svar, som kan afledes både af Kierkegaards tænkning og af de nævnte lingvistiske analyser.

Alligevel trænger der sig en afgørende forskel på. For mens Brown og Levinson tolker den indirekte meddelelse som et redskab, der bruges, til at optimere ens egen situation, fastholder Kierkegaard en indirekthed i den menneskelige tale, der ikke er til at komme udenom. For menneskets begrænsede selvforståelse begrænser på forhånd vores indsigt og forståelse af, hvad det egentlig er, vi siger til hinanden.

Denne divergerende tolkning af de forskydninger, der findes mellem ytring og mening, indebærer dermed også forskellige konsekvenser for de hensyn, der burde tages i en samtale. Disse grundlæggende overvejelser føres videre i afsnit 3. Men først skal en gennemgang af den til dels kritiske reception af Browns og Levinsons projekt påpege yderligere anknytningspunkter mellem Kierkegaard og høflighedsforskningen.

\section{Reception og kritik af Browns og Levinsons projekt}

Browns og Levinsons forskning tilkendes et højt teoridannende potentiale. Roger D. Sell opfatter deres analyser som pendant til Marx' teori om klassekampen, til Freuds sexualteorier samt til Adlers magtanalyser.' Steffen K. Herrmann og Hannes Kuch påpeger dog også, at der kan sættes spørgsmålstegn ved projektets rationalitetsbegreb samt dets krav på at være en universelt gældende forklaringsmodel. ${ }^{10}$

$\mathrm{Og}$, som det ligeledes fremføres af Roger D. Sell, formuleres kritikken til dels endnu mere elementært. Har det nogensinde været tilstrækkeligt at være høflig, for at opnå sine mål? Er kommunikationen

9. Roger D. Sell, "Literary texts and diachronic aspects of politeness", Politness in Language. Studies in its History, Theory and Practice, red. Richard J. Watts, Sachiko Ide, Konrad Ehlich (Berlin / New York: Mouton de Gruyter 1992), 112.

10. Jf. Herrmann \& Kuch (2007), 23. 
ikke kun magtens overflade? Og skal analysen derfor ikke begynde med at undersøge de pågældende magtforhold? (jf. Roger D. Sell 1992, 114f).

På den anden side kan der dog også påpeges et gensidigt forhold mellem magt og kommunikation. Ligesom magtstrukturer kan være afgørende for de enkelte aktørers taleadfærd, har omvendt også aktørernes kommunikationsevner - deriblandt ikke mindst deres informationsadministration - en afgørende indflydelse på deres relationer.

I forlængelse af Browns og Levinsons banebrydende projekt har det derfor været nærliggende, også at rette fokus mod uhøflighedens strategier. Forskningen på dette område blev dog først etableret omkring årtusindskiftet (jf. Bousfield 2008, 1-3). Centralt indenfor denne nyere forskning står undersøgelser af sproglige overgreb i konfliktsituationer, samt spørgsmålet om hvordan disse overgreb kan modsiges og kontrolleres (jf. Bousfield 2008, 4). Blandt andet eftervises kombinerede strategier, som både angriber det negative og det positive ansigt $\mathrm{i}$ den samme talehandling. Men hvordan kan det offentlige selvbillede forsvares?

I denne sammenhæng analyseres strategier med hensyn til den situationelle kontekst og til givne kommunikative optioner. Her fremhæves, at en given magtposition ikke automatisk indebærer retten til at udføre ansigtstruende talehandlinger, men at magten tværtimod begrænser disse handlingernes tilladelige former og grader. Omvendt vises, hvordan den underlegnes muligheder for at forsvare sit offentlige selvbillede på forhånd kan være begrænsede eller endda helt udelukkede. Samtidig findes der en række lingvistiske taktikker, hvormed et forsvar kan manipuleres og forhindres (Bousfield 2008, 263). Disse undersøgelser tager desuden særligt hensyn til samtalernes begyndelse, midte og afslutning. Derved afsløres forsvarsstrategier, der kan bruges i hver fase af samtalen.

Og pointen er opsigtsvækkende. For de to universelle forsvarsmuligheder, der kan bruges i alle faser, har et udpræget passivt træk: den ene består i en ignorering af den ansigtstruende handling, den anden i en stiltiende tilbagetrækning.

\section{Analyser af sproglige uhøfligheder hos Kierkegaard?}

Umiddelbart synes disse studier ikke at have meget berøring med Kierkegaard. Men overvejelser over hvordan vi kan reagere, når vores "ansigt" bliver såret, er faktisk også et bibelsk tema af første rang, som Kierkegaard eksplicit forholder sig til.

Ikke mindst de to ovennævnte forsvarsstrategier vækker associationer til Jesu bjergprædiken, især til afsnittet om gengældelse Matt 5,38-42. Derudover kan der tænkes på afsnittet om fjendekærlighed Matt 5,43-48, og på den bibelske stillingtagen til forhånelser, 
bagtalelser og æreskrænkelser for Kristi skyld, fx Matt 5,11f. Ud fra en ikke-teologisk tilgang synes den moderne Impolitenessforskning netop med dens pointering af gengældelsesfrie reaktionsmønstre at imødekomme bjergprædikens intention.

Også Kierkegaard diskuterer en overvindelse af gengældelsens mekanismer, blandt andet i forbindelse med Jesu og disciplenes reaktion på forhånelser og svig. ${ }^{11}$

Dermed synes gengaldelsen at være et egnet emne for en fælles drøftelse af konfliktundgående talestrategier hos Kierkegaard hhv. høflighedsforskningen.

Et nærmere syn på problematikken vil dog også afdække afgørende forskelle. For mens der i Impolitenessforskningen analyseres, hvordan den underlegne kan undgå yderligere magtovergreb, og hvordan vedkommende derved agerer af hensyn til sig selv, begrundes det samme adfærd hos Kierkegaard af hensyn til den krænkende modpart. ${ }^{12}$ Dermed tilbyder det sig, at overveje Kierkegaards tolkning som et alternativ til de beskrivelser af magtforholdene, som sociolingvistikken tager udgangspunkt i. For i hvilket henseende kan den, der tager hensyn til modparten, netop derved frigøre sig fra sin position som den underlegne? Og hvorvidt øges det konfliktundgående potentiale i de nævnte strategier, når de tolkes i et kierkegaardsk perspektiv?

\section{Kierkegaard om differensen mellem ytring og mening}

"Samfundet antager ikke blot, som jeg seer Chineserne gjøre, 5 Cardinal-Dyder (Høflighed er den 5te), nei, Samfundet antager, etablerer kun een: Høllighed" (NB 29: 50 (1854) SKS 25, 325).

Som denne dagbogoptegnelse antyder, tager Kierkegaard afstand til emnet "høflighed". I stedet for efterlyser han redelighed, og i forbindelse med dette eksistentielle engagement problematiserer han, hvorvidt en direkte meddelelse overhovedet er mulig. Kierkegaard påpeger en fremherskende diskrepans mellem ytring og mening, som han fører tilbage på den menneskelige selvforståelse og dens til dels sproglige konstitution.

I denne sammenhæng skelner han mellem to former for forståelse, hvor han sætter en udelukkende reproducerende forståelse op imod

11. Jf. fx henvisningen til Matt 5,11f hhv. Luk 6,26 i Christelige Taler. Tanker som saare bagfra VI: Det er dog saligt, at lide Forhaanelse for en god Sag (SKS 10, 230-240, 237). Gengældelsen tematiseres desuden fx i Kjerlighedens Gjerninger (SKS 9, 377f). 12. Jf. fx Kierkegaards analyse af det blik, som Jesus ser på Peter med efter hans fornægtelse. Analysen findes i Kjerlighedens Gjerninger, i talen I. IV. Vor Pligt at elske de Mennesker, vi see (SKS 9, 171). 
en eksistentiel tilegnelse af de udtalte ord. Således hedder det i Begrebet Angest: "At forstaae en Tale, er eet, at forstaae det Deiktiose deri, er et Andet, at forstaae, hvad man selv siger, er eet, at forstaae sig selv i det Sagte, er et Andet" (SKS 4, 442).

Her efterlyses den talendes selvforstålse i det sagte. Men betyder det, at afstanden mellem ytring og mening bunder i en mangelfuld selvindsigt, mens en overensstemmelse kun er muligt, når mennesket bliver gennemsigtigt for sig selv?

For i det mindste at antyde konturerne af dette spørgsmål, vil jeg i det følgende tilføje nogle overordnede overvejelser angående forholdet mellem menneskets selvforståelse og sprogbrug. Emnet er dog så omfattende, at det i denne sammenhæng på ingen måde kan behandles tilstrækkeligt. ${ }^{13}$

Men Kierkegaards diskussion af den menneskelige tale som forankret i menneskets selvforståelse fremstår som en afgørende forudsætning, også for relationen mellem afsenderen og modparten i en given samtale. De følgende overvejelser vil dermed udelukkende gøre opmærksom på problemstillingen, uden at jeg her kan drøfte emnet yderligere.

I det følgende vælger jeg dermed, at koncentrere mig om Kierkegaards konfrontation af de to udtryk "menneskelig talt" og "christelig forstaaet", ${ }^{14}$ som særlig konsekvent udfoldes i værket Sygdommen til Døden (1849). ${ }^{15}$

I dette værk optræder udtrykket "menneskelig talt" især i indledningen og desuden i den antropologiske første del af skriftet, i de to afsnit C.A.b)beta) ${ }^{16}$ og C.B.b)alpha) 1). ${ }^{17}$ I afsnittet C.A.b)beta) analyseres nødvendighedens fortvivlelse som det at mangle mulighed. Og i afsnittet C.B.b)alpha)1) drøftes fortvivlelsen over det jordiske eller over noget jordisk. Allerede denne placering af udtrykket antyder, hvad der antages som begrænsning for det, der "menneskelig talt" kan siges. Den menneskelige tale tager udgangspunkt i endeligheden,

13. "Selvforståelse" er et bredt diskuteret emne indenfor den aktuelle Kierkegaardog Subjektivitetsforskning. Jf. fx Subjectivity and Transcendence, red. Arne Grøn, Iben Damgaard \& Søren Overgaard (Tübingen: Mohr Siebeck 2007).

14. Til disse udtryk kan sammenlignes: Vannessa Rumble, "Christianly Speaking, Humanly Speaking: The Dynamics of Leveling and Mimetic Desire in Kierkegaard's Christian Discourses", SKYB (2007), 209-226.

15. Formuleringen "menneskelig talt“ er meget udbredt i forfatterskabet. Den findes blandt andet i Gjentagelsen, Frygt og Baven, i Opbyggelige Taler (1843) og (1844); Stadier paa Livets Vei, Lidelsernes Evangelium, Kjerlighedens Gjerninger, Christelige Taler, Indøvelse i Christendommen m.m.

16. $S K S$ 11, 153-157.

17. $S K S$ 11, 165-175. 
og den respekterer endelighedens erfaring som begrænsning for alt det, vi kan ytre os om.

Allerede i "indgangen" af værket Sygdommen til Døden, som omhandler den bibelske beretning om Lazarus' opvækkelse (Joh 11), får den menneskelige tale anvist sin plads indenfor endelighedens betingelser. "Thi menneskelig talt er Døden det Sidste af Alt, og menneskelig talt er der kun Haab saalænge der er Liv" (SKS 11, 124).

Denne klare afgrænsning fastslår tillige, hvad der menneskelig talt er muligt. Betegnende nok begynder netop det afsnit, hvori nødvendighedens fortvivlelse bestemmes som det at mangle mulighed, med følgende billede:

Dersom man vilde sammenligne det at løbe vild i Mulighed med Barnets Vokaliseren, saa er det at mangle Mulighed som det at være stum. Det Nødvendige er som lutter Konsonanter, men for at udtale dem maa der Mulighed til. Naar denne mangler, naar en menneskelig Existents er bragt dertil, at den mangler Mulighed, er den fortvivlet, og er det i ethvert Øjeblik, hvor den mangler Mulighed (SKS 11, 153).18

Dette billede har en speciel pointe. Begrænsningen af det, der menneskeligt set er muligt, medfører, at det, der menneskeligt kan siges, er så vidtgående fordunklet, ${ }^{19}$ at det kan sammenlignes med en væsentlig stumhed. Men under denne forudsætning kommer den menneskelige tale ikke til det sande (jf. SKS 11, 153).

Tilsvarende forlyder det $\mathrm{i}$ analysen angående fortvivlelsen over det jordiske eller over noget jordisk: Når mennesket ligger under for "Udvorteshedens Tryk", medfører det et "uskyldig Misbrug af Sproget", "en Leeg med Ord", som dog på samme vis som børnenes soldaterleg mangler en dybere bevidsthed om selvet (jf. SKS 11, 165). Under begrebet "Udvorteshedens tryk" omtales en form for nødvendighed, overfor hvilken mennesket ikke er i stand til at finde adgang til det mulige. Men i denne tilstand bliver "[d] et hele Spørgsmaal om Selvet

18. Dette billede, som tager udgangspunkt i det hebraiske sprogs særegenheder, har Kierkegaard ikke selv opfundet. Det findes allerede i et brev fra Hamann til Kant fra året 1759. Yderligere referencer til stedet findes hos J. Ringleben, Die Krankheit zum Tode von Sören Kierkegaard. Erklärung und Kommentar. (Göttingen, Vandenhoeck\&Ruprecht 1960), 157, Anm. 255. Kierkegaard har dog udvidet dette billede ved at tilføje den indledende sammenligning mellem det at fare vild i muligheden og barnets vokaliserende pludren.

19. I Sygdommen til Døden diskuteres en "Erkjendelsens og Selverkjendelsens Klarhed" (SKS 11, 162) overfor en "Halv-Dunkelhed" (SKS 11, 163), der bestemmes som den fortvivledes tilstand. Dunkelheden og uvidenheden føres her tilbage på "et dialectisk Sammenspil af Erkjendelse og Villie" (dss.). En lignende konfrontation fremføres i talen Guds Uforanderlighed, hvor dunkelhederne i den omskiftelige menneskelige tilværelse stilles overfor Guds uforanderlige klarhed (SKS 13, 331). 
i dybere Forstand [...] en Slags blind Dør i Baggrunden af hans Sjel, indenfor den er der Ingenting" (SKS 11, 171).

Også billedet af den blinde dør symboliserer på sin vis en væsentlig stumhed. Godt nok bliver der talt alligevel, og det på menneskelig vis. Men det, som mennesket under det ydres pres "i sit Sprog kalder sit Selv" (SKS 11, 171), er væsentlig kun en efterabelse (jf. SKS 11, 168) af andres liv.

Hvad kan der sættes op imod denne fordunkling? Det er her differentieringen mellem Kierkegaards to udtryk "menneskelig talt" og "christelig forstaaet" gør sig gældende. "Christelig forstaaet" fører troen på, at "for Gud er Alt muligt" (SKS 11, 154), den menneskelige tale ud af dens blindgyde. For hvis Guds vilje "blot [er] det Nødvendige, er Mennesket væsentligen lige saa umælende som Dyret" (SKS $11,156)$. Men fordi Guds vilje er det mulige, derfor er mennesket i stand til at meddele sig. ${ }^{20}$

Klarheden over, hvad der udgør menneskets selv, grunder dermed i en åbning overfor det mulige. Og ifølge Kierkegaard er det netop den kristelige forståelse, hvorefter Gud opfattes som indbegrebet af det mulige, der tildeler den menneskelige tale den ånd, hvori det sagte kan tolkes på rette vis (jf. SKS 11, 155).

Denne analyse har tillige konsekvenser for opfattelsen af den måde, vi kan tale til hinanden på. For det første tematiseres her, at den enkeltes gudsforhold også kvalificerer vedkommendes relationer til andre mennesker, hvorved netop gudsforholdet danner en grundlæggende præmis for selve kommunikationen. $\mathrm{Og}$ for det andet påpeges her den forpligtelse, at enhver kommunikation må give plads for det mulige. Og denne indrømmelse gælder både i forhold til den talende og i forhold til modtageren.

Hvorvidt vi i en samtale kan vise hensyn overfor hinanden, bestemmer Kierkegaard dermed uafhængigt af sproglige konventioner. Tværtimod begrunder han dette hensyn i det omfang af mulighed, som den talende indrømmer i forhold til sig selv og til modtageren.

Selvom Kierkegaard ikke vægter høflighedens konventioner særlig højt, er det alligevel nærliggede, at relatere hans krav om en indrømmelse af det mulige til fx Browns og Levinsons påvisning af de krav, der knytter sig til modtagerens positive ansigt.

For en kommunikation der anerkender både den talendes og modtagerens mulighed ( $\mathrm{fx}$ konkret opfattet som mulighed for at realisere det gode), forholder sig derved til det positive ansigt og dets behov. Og mulighedens dimension tilføjes ved, at selve ytringen formidler et overskud, der hverken sættes ord på eller kan sættes ord på. Dermed

20. Nøjagtigere sagt: Derfor er mennesket i stand til at bede, (jf. SKS 11, 156). 
bliver netop afstanden mellem ytring og mening den afgørende garant for et indirekte tilsagn af det mulige.

\section{Særlige hensyn ved samtalernes begyndelse og afslutning}

Men hvordan kan "det muliges dimension" inddrages i det, vi siger til hinanden? Jeg vil udfolde denne delkonklusion fra afsnit 3 lidt nærmere, ved at tilføje enkelte overvejelser angående den menneskelige samtales begyndelse og afslutning.

Både ved begyndelsen og ved afslutningen af en samtale (og tilsvarende ved ethvert menneskelivs begyndelse og afslutning) ligger det særligt nært at rette en øget opmærksomhed på det mulige. Samtidig består der både ved begyndelsen og ved afslutningen en særlig chance for at imødekomme den andens positive ansigt, uden at den der tiltales hverken behøver eller kan gøre sig fortjent til det.

I slutningen af afsnit 2 har jeg meget kort nævnt sociolingvistiske analyser af forskellige faser $\mathrm{i}$ en samtale. Til disse analyser vil jeg nu knytte enkelte refleksioner angående samtalernes begyndelse og afslutning, ved at inddrage to af Kierkegaards taler fra hhv. 1844 og 1845.

\section{At begynde en samtale}

I sin opbyggelige tale Imod Feighed (1844) gør Kierkegaard opmærksom på en konventionalisering af sprogbrugen, hvorved han samtidig antyder en omfattende kulturkritik. Han skriver:

Det skal være Tegn paa en forfinet Tidsalder, at man giver det Utilladelige, det Forbudne, Synden et undskyldende, næsten et hæderligt Navn. Stundom fortsættes Falskneriet saa længe, at det gamle, alvorlige, bestemte Ord glemmes og gaaer af Brug $(S K S$ 5, 340).

Her defineres den høflige tale først og fremmest gennem en udeladelse af bestemte ord og emner. Den høflige tale nævner ikke direkte det utilladelige, det forbudne og det tabuiserede, men den koncentrerer sig om emnernes positive konnotationer. Med denne analyse fokuserer Kierkegaard i øvrigt på en problematik, der hos Brown og Levinson tematiseres i forbindelse med de talehandlinger, der nævner tabuiserede emner og således ikke anerkender modpartens positive ansigt (jf. afsnit 2). Men til forskel fra deres analyse retter Kierkegaard her ikke fokus mod afsender-modtagerrelationen i samtalen. Han er 
derimod optaget af samtalens saglige dimension. ${ }^{21}$ For allerede valget af selve emnet er afgørende for samtalens kvalitet. Hvad taler vi om? Og hvad taler vi ikke om?22

Dette kriterium gør selve begyndelsen til et kritisk punkt. ${ }^{23}$ Tilsvarende tematiserer Kierkegaard i sin opbyggelige tale Imod Feighed netop begyndelsens forudsætninger. Begyndelsen som sådan er en beslutning. Men en beslutning må kunne fattes i ord. Og dermed åbner der sig allerede på dette sted en valgmulighed mellem ordenes dobbelte hhv. multiple betydningshorisont. Samtidig skal der endnu inden ordene vælges - vælges en holdning hvorudfra der tales. Kierkegaard konfronterer stolthed og fejhed og antyder dermed betydningen af, hvordan jeg stiller mig overfor mig selv og modtageren.

Enhver af disse valgsituationer afdækker samtidig endnu flere forudgående valgmuligheder. Og i ét med det tilspidses begyndelsens problematik. For hvordan skal der begyndes? Talen Imod Feighed demonstrerer denne vanskelighed, ved at den indledes med en række tilsyneladende begyndelser, der ligesom stammende undgår at markere et klart startpunkt, men gang på gang forhaler, at der kan begyndes.

Men denne forhaling er i sig selv et udtryk for fejhed. Fejheden begynder ikke, den tøver. Det gælder også samtalens begyndelse. For selvom der allerede kommer ord ud af min mund, er det langtfra ensbetydende med, at jeg allerede skulle være begyndt at sige noget. Kierkegaards konsekvente afstandtagen fra alle former for (præste-) sludder og vrøvl danner her en bagvedliggende klangbund. ${ }^{24}$ Hvornår starter det, at man siger noget? Afgøres også det af det valgte emne?

I sin tale Imod Feighed fremhæver Kierkegaard, at hvert fænomen indenfor lidenskaberne har to sider. Således er fejheden bagsiden af den mønt, hvis forside klædes af stoltheden. Om der derfor tales om stolthed eller fejhed, fremhæves dog det samme fænomen. Alligevel er det af hensyn til modtageren på ingen måde ligegyldigt, hvilket ord

21. Jf. fx følgende notat: "For at undgaae Scandale tier man stille, indulgerer Foragtelighed, Usselhed, Løgn: man mærker ikke, at den Scandale, der saaledes afstedkommes er uendelig fordærveligere. Saadant er nu Verdens Tyve-Sprog, naar En paataler den faktiske Nederdrægtighed, saa siger man; det er ham, der vækker Scandale; thi den faktiske Nederdrægtighed det er ingen Scandale, der er formodentlig slet ingen Ting" (NB 16: 53 (1850), SKS 23, 131).

22. Dette valg tematiseres $\mathrm{fx}_{\mathrm{i}} \mathrm{i}$ alternativet mellem at tale om andres uret hhv. at tale om Guds nåde, som opstilles i slutningen af Kjerlighedens Gjerninger (SKS 12, 378) eller i alternativet mellem at tale om den jordiske armod hhv. den himmelske rigdom, der opstilles i den Christelige Tale Armodens Bekymring (SKS 10, 29).

23. Kierkegaards diskussion af begyndelsens dialektik relateres tæt til hans opgør mod Hegel, jf. Wind (1987), 68.

24. Jf. fx JJ: 96 (1843), SKS 18,170 og NB: 21 (1846), SKS 20, 30. Sidstnævnte optegnelse med referencer til Hamlets død slutter med sætningen: „Selv en tilsyneladende consequent Begyndelse ender altid i Sludder." 
der bliver brugt. Godt nok er det falskneri, når man bevidst foretrækker ordets positive konnotation fremfor dets negative bagside. Men alligevel benytter høfligheden sig af netop denne strategi.

Kierkegaard afviser ikke at der tages hensyn. Men han tillader sig et kritisk blik på det, der bliver sagt. Og her påviser han blandt andet en undgåelse af samtaleemner. Således kan hele betydningskomplekser - for eksempel enhver omtale af synden - fortrænges ud af det daglige sprogbrug og den almindelige bevidsthed.

Men også denne undertrykkelse af, at en sag kaldes ved dens rette navn, er en forhaling. For der sker en forhaling af en tilbundsgående erkendelse af den relevante sag, og samtidig bidrager denne forsinkelse til at udskyde nødvendige handlinger og forandringer. Og i denne sammenhæng rykker fejhed og høllighed tæt på hinanden - uden at de dog nødvendigvis kan identificeres med hinanden.

Høflighed er falskneri. Men dens tøvende selv-tilbageholdelse kan også forklares ud fra andre motiver. Den kan for eksempel være motiveret af en hensyntagen, som giver den anden lov til at udtale sig først. Eller den kan være motiveret af en bevidsthed om, at mine ord er kvalificeret af, at jeg på forhånd er tiltalt af Gud.

En undgåelse af negative konnotationer kan dermed også tolkes som den talendes positive reaktion på det muliges horisont, som vedkommende på forhånd har fået indrømmet af Gud.

Overfor bedrageriske og feje måder at kommunikere på, synes det dermed oplagt, at udvikle et koncept for den varsomme tale, der rettes mod at imødekomme den andens krav på anerkendelse af sit positive selvbillede.

\section{At afslutte en samtale}

Også ved afslutningen af en samtale ligesom ved afslutningen af relationer må der ifølge Kierkegaard gives plads for det mulige. Dette krav påpeges særdeles tydelig i talen Ved en Grav. ${ }^{25}$ Også denne tale tager emnet "fejhed" op og viser, hvordan den til forskel fra alvoren opfatter døden. Igen er det to forskellige forståelsesformer, der konfronteres med hinanden. For mens fejheden overgiver sig til stemninger, svarer "den Alvorlige [...] slet Intet, og endeligen siger han, dog uden at spotte, med Alvorens Rolighed: “ja, det er muligt!” (SKS 5, 462). Denne replik gentages endda hele tre gange. Alvoren tier, ser roligt på den lærende og siger: “ja, det er muligt!” (SKS 5, 463). Og muligheden for selv at blive alvorligt, begrundes ud fra det dialektiske

25. Tre Taler ved Tankte Leiligheder (1845), 3. tale, SKS 5, 442-469. En vejvisende analyse af denne tale findes i: Michael Theunissen, "Das Erbauliche im Gedanken an den Tod. Traditionelle Elemente, innovative Ideen und unausgeschöpfte Potentiale in Kierkegaards Rede: 'An einem Grabe'”, KSYB (2000), 40-73. 
forhold mellem dødens vished og den uvished, der fortsat knyttes til døden. For, som Kierkegaard konstaterer: "Visheden er den Uforanderlige, og Uvisheden er det korte Ord, det er muligt, [...] og al Lidenskabelighed og al Snildhed og al Trods gjøres afmægtig ved dette Ord, indtil den Lærende gaaer i sig selv" (SKS 5, 463).

I idealtilfældet indrømmer mennesket dermed både ved begyndelsen såvel som ved afslutningen af de relationer, som det indgår i, at "alt er muligt." Og selvom den menneskelige kommunikation er præget af en indbygget afstand mellem det, der siges, og meningen bag ved de udtalte ord, så brydes denne indirekthed, hver gang, når vi tilsiger hinanden, at "alt er muligt". Her må modtageren få en klar fornemmelse af, at jeg virkelig mener det, jeg siger.

Omvendt er det dermed også et tegn på tillid og anerkendelse, at den anden ikke sætter spørgsmålstegn ved min indrømmelse af det mulige. Netop med henblik på denne indrømmelse indskærper Kierkegaard kravet om en klar overensstemmelse mellem ytring og intention:

See, man kan have en Mening om fjerne Begivenheder, om en Naturgjenstand, om Naturen, om lærde Skrifter, om et andet Menneske, og saaledes om meget Andet, og naar man ytrer denne Mening, kan den Vise afgjøre, om den er rigtig eller urigtig. Derimod uleiliger Ingen den Menende med at betragte Sandhedens anden Side, om man nu virkelig har Meningen, om den ikke er Noget, man fremsiger. Og dog er denne anden Side ligesaa vigtigt, thi den er jo ikke blot afsindig, der siger det Meningsløse, men lige saa fuldt Den, der siger en rigtig Mening, naar denne slet og aldeles ingen Betydning har for ham. Det ene Menneske viser det andet den Tillid, den Anerkjendelse at antage, at det er hans Mening, naar han siger det (SKS 5, 467).

Parallelt til Kierkegaards adskillelse mellem to forståelsesformer konfronteres her to måder at ytre en mening på. Og forskellen bestemmes gennem det personlige engagement: Siger jeg noget, som bare er korrekt, eller ytrer jeg en mening, der betyder noget for mig?

Denne kongruens mellem Kierkegaards bestemmelse af forståelsens hhv. meningens dobbelte udfordringer må dermed forstås på baggrund af den væsentlige relation mellem menneskets selvforståelse og dens sproglige realisering. Først når jeg siger, hvad jeg mener, forstår jeg mig selv i det sagte, ligesom den rette selvforståelse omvendt opfattes som forudsætning for, at jeg overhovedet kan sige hvad jeg mener.

Netop med henblik på dette idealtilfælde viser det sig som imødekommenhed overfor den talende samt overfor de behov, der knytter sig til hans positive ansigt, at modtageren ikke stiller spørgsmålstegn ved den intenderede overensstemmelse mellem ytring og mening. For når både den talende og modtageren forholder sig til de begrænsnin- 
ger, der knytter sig til den menneskelige selvindsigt, opstår muligheden for en autentisk selvmeddelelse og kommunikation.

\section{Konklusion}

Ovenstående overvejelser skulle påpege potentialet $\mathrm{i}$ en eventuel dialog mellem konkrete sociolingvistiske tilgange og Kierkegaard. Til dette formål har jeg konfronteret høflighedsforskningens fokus på samtalepartnernes behov med Kierkegaards opmærksomhed på de talendes selvforståelse. Derved blev der afsløret en diskrepans mellem de hensyn, der i begge tilløb tages til den talende hhv. til modtageren samt en diskrepans i vurderingen af disse hensyn. Ikke mindst vil høflighedens konfliktundgående hensyn ud fra Kierkegaard ofte kunne tolkes som et svigt overfor modtagerens krav på afsenderens redelighed. ${ }^{26}$

Forenklet sagt: mens den hølige tale prøver på ikke at virke sårende, kæmper Kierkegaard mod falskneri. ${ }^{27}$ Netop denne forskellige tilgang gør det oplagt, at diskutere Kierkegaard som muligt korrektiv overfor hølighedsforskningens strategiske hensyn.

Som alternativ til den høflige tale vil det dermed være oplagt, at drøfte et koncept for den varsomme tale. Det vil sige for en form for samtale, der er varsom i den forstand, at den tager hensyn til menneskets begrænsede selvindsigt. For hvad gør det ved mig, når jeg ikke kan sige, hvad jeg mener? Og hvad gør det ved modtageren, når jeg siger noget andet, end det jeg mener? Og hvordan kan der indøves en bevidsthed af uundgåelige diskrepanser mellem ytring og intention?

"Kan du nå saltet?" I Kierkegaards univers er det nærliggende, at associere dette spørgsmål til en specifik bibelsk opfattelse af selve motivet. "Bevar saltet i jer selv, og hold fred med hinanden" (Mark

26. Jf. især NB 28: 76 (1854) (SKS 25, 275). I dette notat angriber Kierkegaard en høflig udeladelse af "paa nogensomhelst personlig Maade at tale til den Anden om Evigheden og Salighedens Sag” (dss).

27. I denne sammenhæng kan også henvises til Kierkegaards analyser af hykleri, som han blandt andet definerer som et ønske om "at ville være ganske som de andre" (NB 31: 56 (1854) SKS 26, 40). 
9,50b). ${ }^{28}$ Mon ikke også denne opfordring motiverer en specifik varsom måde at tale på, der fortjener at blive drøftet? ${ }^{29}$

28. Vedr. den bibelske brug af saltmetaforikken jf. fx 2 Krøn 13,5; 3 Mos 2,13; Matt 5,13; Mark 9,49 f; Luk 14,34; Kol 4,6. Kierkegaard var især opmærksom på saltsymbolikken i forbindelse med offergaver. Således skriver han i avisartiklen "Salt" i Fædrelandet, den 30. marts 1855: "det at være Christen er at være Salt og Villighed til at offres" (SKS 14, 173).

29. Tak til Elna Carlsen for en sproglig revision. Desuden en særlig tak til de to anonyme forfattere af peer reviews, hvis konstruktive kritik og forslag til dels har fundet indgang i den aktuelle version af denne artikel. 